\title{
Exploring the Connections between Agroecological Practices and Ecosystem Services: A Systematic Literature Review
}

\author{
Sara Palomo-Campesino ${ }^{1,2}$, José A. González ${ }^{2}$ [D and Marina García-Llorente ${ }^{1, *(1)}$ \\ 1 Department of Applied Research and Agricultural Extension, Madrid Institute for Rural, Agricultural and \\ Food Research and Development (IMIDRA), Ctra. Madrid-Barcelona (N-II) KM. 38.200, \\ 28802 Alcalá de Henares, Madrid, Spain; sara.pal.cam@gmail.com \\ 2 Social-Ecological Systems Laboratory, Department of Ecology, Autonomous University of Madrid, \\ 28049 Madrid, Spain; jose.gonzalez@uam.es \\ * Correspondence: marina.garcia.llorente@madrid.org; Tel.: +34-918879392
}

Received: 26 September 2018; Accepted: 21 November 2018; Published: 22 November 2018

\begin{abstract}
Current patterns of global change are threatening the supply of agrarian ecosystem services on which human well-being depends. Within this context, agroecology has emerged within political and scientific arenas as a socially equitable and ecologically sustainable alternative to conventional agriculture. We performed a systematic literature review to explore how agroecology and the ecosystem services framework have been adopted together in the scientific literature, focusing on studies including empirical data on the effects of agroecological practices on the supply of ecosystem services. In our search, we combined terms related to agricultural practices and terms related to ecosystem services. A total of 179 scientific articles were analyzed. Most of the studies used a biophysical approach to evaluate ecosystem services, with regulating and provisioning services being more frequently analyzed than cultural services. More than half of the analyzed relationships between agroecological practices and ecosystem services were positive. Remarkably, our review showed that many of the ten elements of agroecology defined by the FAO have not been properly addressed in the literature. Finally, we identified research gaps and provided insights on where future research and policies should be focused in order to promote the transition towards sustainable agrarian social-ecological systems that increase the supply of ecosystem services while minimizing environmental impacts.
\end{abstract}

Keywords: agricultural landscapes; agroecosystem; agroecological practice; ecosystem service; systematic review

\section{Introduction}

Currently, agricultural systems are the most widespread land use on the planet, with permanent crops and pastures covering more than $37 \%$ of the terrestrial global surface [1,2]. The so-called Green Revolution (which emerged in the 1940s and spread worldwide during the 1960s and 1970s) introduced a new standardized set of technologies and high-yielding crop varieties within agricultural systems in the search for solutions to world hunger and food deprivation [3]. Although this renovation partially contributed to increased crop yields and addressed food insecurity, hunger and malnutrition still prevail. The Green Revolution also triggered several negative social-economic and environmental impacts, such as the marginalization and discrimination of smallholders without capital and land who cannot afford the new technological resources; the dissolution of self-provisioning agriculture systems; the erosion of genetic resources and the loss of biodiversity; the regression of cultural identities, practices, and agricultural knowledge; the overuse of freshwater; the pollution of water and soil; a 
reduction in soil fertility and an increase in soil erosion; the emission of greenhouse gases, etc. [4-11]. The projected growth from current over 7.5-billion world population to 9.7 billion in 2050 [12] raises questions about how agricultural systems should be adapted to supply enough food to satisfy the growing demand while maintaining ecosystem health and fostering social equity [13]. To address this situation, conflicting approaches have been proposed by different researchers and stakeholder groups. While some authors defend the position of enhancing the efficiency of agricultural technologies, such as biotechnology or precision agriculture [14-17], others maintain the idea that the existing gap between food production, ecosystem sustainability and social equity can only be addressed through the implementation of more sustainable and ecologically based agroecosystems [18-22].

Agroecology is considered by several authors to be a win-win solution to the problem described above. This term was first used by the Russian agronomist Basil Bensin in 1928 to refer to the combination of ecology and agriculture; thus, it was defined as a science related to other disciplines, such as zoology or plant physiology [23]. Through the subsequent decades, the term agroecology evolved and gradually introduced other dimensions of the food chain supply, acknowledging the importance of connecting producers and consumers and reducing the social-ecological impacts of the intermediary system [24-27]. This evolution led to the current consideration of agroecology not only as a scientific discipline but also as a social-political movement and a set of practices [23,28]. However, it was not until the 1970s and 1980s when the concept "agroecology" began to be increasingly mentioned in the scientific literature, from two papers using this term in 1971 to 458 in 2017 (data from Web of Science). Additionally, regardless of the fact that agroecology is not market-driven or unanimously defined within the political and scientific arenas [29], the use of this concept and the inclusion of its principles in public policies and global agencies' publications are currently developing [30-34]. As a recent example, the Food and Agriculture Organization of the United Nations (FAO) published a document proposing the ten elements of agroecology in which the common characteristics of agroecological systems are defined, and key considerations in preparing and enabling the environment to accommodate agroecology are given. The aim of this document is to guide countries to transform their food and agricultural systems, placing agroecology in a framework that may help policymakers, practitioners and stakeholders in planning, managing and evaluating agroecological transitions. The ten elements are diversity, the co-creation and sharing of knowledge, synergies, efficiency, recycling, resilience, human and social values, culture and food traditions, responsible governance and circular and solidarity economy [32].

Regardless of the increasing inclusion of the agroecology framework in public policies and global agencies, there is still a lack of knowledge about how agroecological practices can enhance the supply of ecosystem services. The ecosystem services concept emerged in the late 1960s [35], although its first mention in a scientific paper was not until 1983 [36]. During recent decades, the "ecosystem

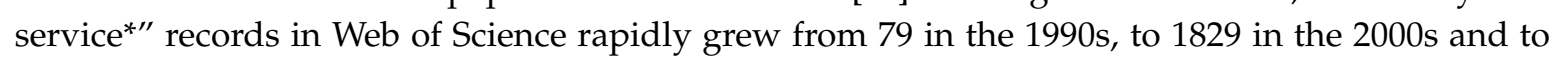
17,526 in 2017, mainly due to the publication of the Millennium Ecosystem Assessment (MEA) in 2005 and the implementation of the Intergovernmental Science-Policy Platform on Biodiversity and Ecosystem Services (IPBES) in 2012 [37]. The Millennium Ecosystem Assessment broadly defined this term as "the benefits people obtain from ecosystems", acknowledging that the linkages and dynamic interactions between people and ecosystems lead to direct and indirect changes in ecosystem services and human well-being [38]. Agroecosystems clearly illustrate those interactions between nature and society, being providers of ecosystem services but also posing some threats and negative consequences for the environment [39]. Within this context, an appropriate selection of agricultural practices may result in an enhancement of the supply of ecosystem services and a reduction in environmental impacts at the farm and landscape scales [39,40].

Here, we performed a systematic literature review to explore how agroecology and the ecosystem services framework have been adopted together in the scientific literature. Our main goals were to (1) identify the agroecological practices and ecosystem services most frequently analyzed in the scientific literature, (2) synthesize the causal links between agroecological practices and ecosystem services 
reported in the literature, and (3) identify the existing knowledge gaps and future research challenges in order to promote a transition towards sustainable agrarian social-ecological systems that increase the supply of ecosystem services.

\section{Materials and Methods}

\subsection{Literature Review and Data Collection}

To conduct our literature review, we adapted the Preferred Reporting Items for Systematic Reviews and Meta-Analysis (PRISMA) protocol [41] to the particularities of our study. First, we performed a Web of Science search up to 2017, including studies that (1) analyzed sustainable agricultural management ( $\mathrm{n}=48$ keywords were used), (2) explicitly used the ecosystem service framework ( $\mathrm{n}=11$ keywords) and (3) were focused on specific ecosystem services mainly related to agricultural systems ( $\mathrm{n}=83$ keywords). Every term referring to any kind of sustainable agricultural management, not only "agroecology", was included as a keyword (see Appendix A for the complete list of keywords used in the systematic review). In this way, we could analyze both the effects of sustainable practices (that are also applicable in agroecological systems) on ecosystem services and the degree to which the agroecology framework has been studied in the scientific literature. We only included original scientific articles in English, excluding meetings, books, letters, editorials and corrections. Review papers were also excluded to avoid replication bias.

We screened the abstracts of the obtained list of papers, excluding those that did not evaluate relationships between sustainable agricultural practices and ecosystem services. The papers with an abstract that fit within our study scope were subsequently reviewed in-depth, and those that did not include information relevant to our aim were excluded. Then, we created a database with information from the selected papers to identify the status and general trends in the scientific literature regarding the combination of agroecological practices and ecosystem services. Specifically, we included the following information: (1) the general data from the papers (e.g., title, authors, year of publication, etc.), (2) the study area (e.g., country, spatial scale, etc.), (3) the crop type categorized according to the FAO's Indicative Crop Classification (ICC) [42], (4) the methodological approach (e.g., social, biophysical or economical approach, quantitative or qualitative data, theoretical or analytical, etc.), (5) the inclusion of the FAO's ten elements of agroecology [32], (6) the type of agricultural management (e.g., agroecological system, organic system, alternative system, etc.), (7) the ecosystem services studied (e.g., food, pest control, traditional ecological knowledge, etc.), and (8) the agricultural practices studied (e.g., cover crops, no tillage, nonuse of agrochemicals, etc.) (see Supplementary Material 1 for the complete list of attributes analyzed). The ecosystem services were named as they appeared in the reviewed papers, and the agricultural practices studied were progressively included in the matrix as they appeared in the literature.

A second database was created with information from the papers that empirically analyzed the relationships between sustainable agricultural practices and ecosystem services. In this database, we incorporated as many rows per paper as the number of "agricultural practice-ecosystem service" links assessed in the paper. For each relationship we included information on (1) the agricultural practice analyzed (e.g., nonuse of chemical fertilizer), (2) the ecosystem service analyzed (e.g., food), (3) the type of sustainable agricultural management system or practice studied (e.g., organic farming), (4) the type of agricultural management system or practice with which the sustainable agricultural system or practice was compared (if applicable) (e.g., conventional farm where chemical fertilizers are applied versus organic farm with the nonuse of agrochemicals), (5) the ecosystem service indicator used to assess the relationship (e.g., total yield per hectare and year), and (6) the type of relationship (positive, negative or non-significant) between the sustainable agricultural practice and the ecosystem service analyzed. We recorded a positive interaction when an agricultural practice has been reported to significantly increase the supply of an ecosystem service. A negative interaction was recorded when the paper reported a significant decrease in one ecosystem service caused by a sustainable agricultural 
practice compared to other conventional practices. A non-significant relationship was considered to occur when the differences in one ecosystem service between sustainable and conventional agricultural practices were statistically non-significant (see Supplementary Material 1 for the complete list of attributes analyzed).

The Web of Science search resulted in a sample of 634 papers, 317 of which were selected for in-depth review after the screening of abstracts. After the complete reading of the papers, 138 were excluded, as they did not study relationships between agricultural practices and ecosystem services. The remaining 179 papers were used to build the first database characterizing research status and trends. Finally, the relationships between agricultural practices and ecosystem services were assessed based on a subsample of 147 papers that provided empirical evidence of those relationships and were used to build the second database (Figure 1; see Supplementary Material 2 for the complete list of papers included).

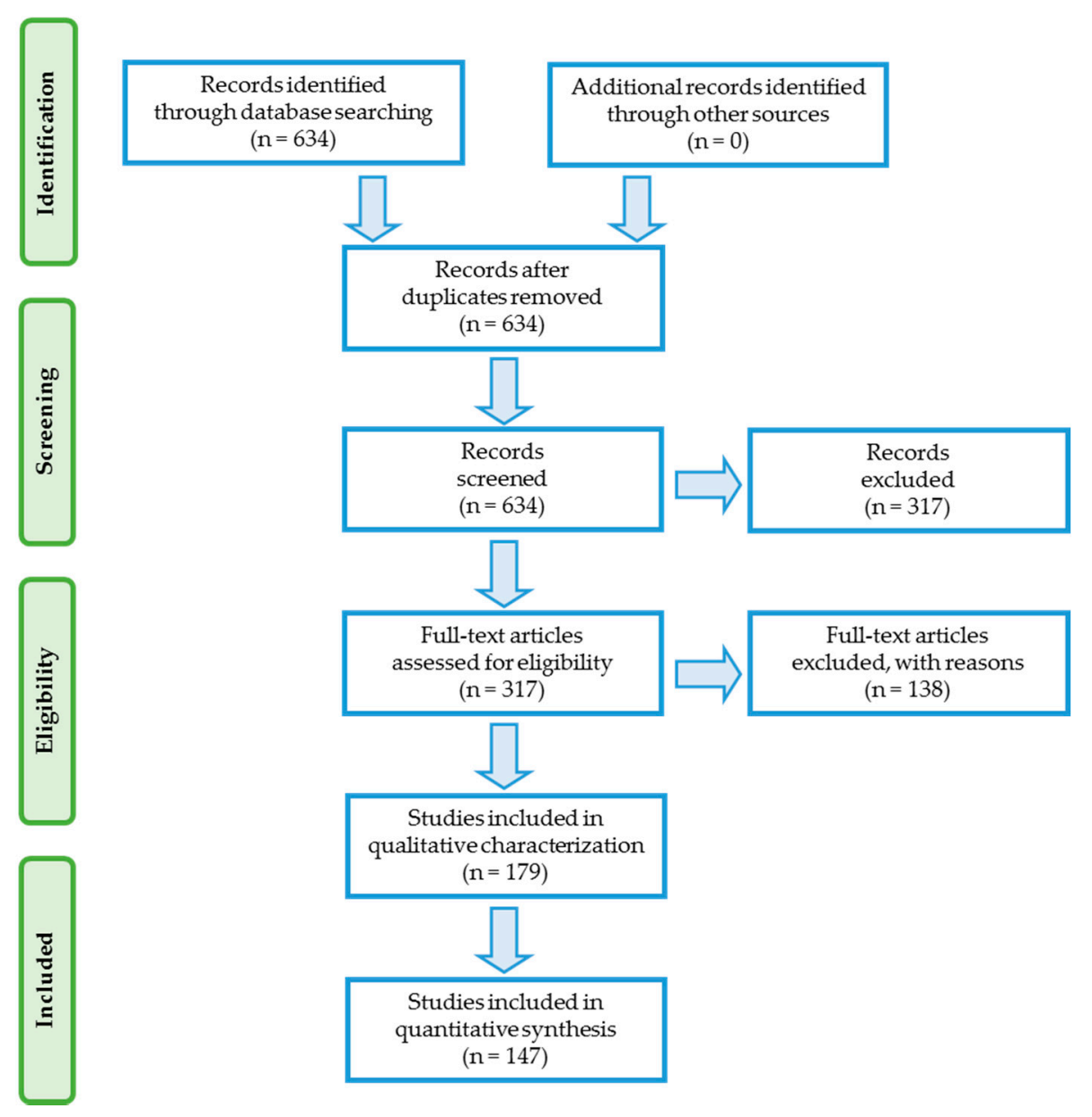

Figure 1. Flow diagram of the literature review process (adapted from PRISMA).

\subsection{Data Analysis}

We characterized the articles included in the first database by performing descriptive statistical analyses and frequency analyses for year of publication, study area, geographical scale, research area in Web of Science, interdisciplinarity of the team, type of methodology used and crop type. To address the current status and general trends of research concerning the inclusion of the agroecology framework and social-political issues within the studies, we analyzed whether the institutional context was addressed, whether the studies mentioned that sustainable agricultural practices have benefits other than the ecological ones, whether the studies included stakeholder participation, whether any of the FAO's ten elements of agroecology were considered [32], and the keywords mentioned in the studies 
that refer to sustainable agricultural management. Finally, we calculated the frequency at which the agricultural practices and ecosystem services were mentioned in the selected papers.

We analyzed the relationships between agricultural practices and ecosystem services based on the empirical data gathered in the second database. For this, we calculated how many times a relationship between an agricultural practice and an ecosystem service has been addressed in the literature, considering only empirical studies with significant results. Then, we calculated the percentages of positive and negative relationships reported. Further, we conducted a redundancy analysis (RDA) to search for linear relationships between agricultural practices and ecosystem services when significant and positive relationships were found between them, using agricultural practices as explanatory variables and ecosystem services as response variables. A Monte Carlo permutation test (1000 permutations) was performed to determine the significance of the explanatory variables.

\section{Results}

\subsection{Status and General Trends of the Research on Agroecological Practices and Ecosystem Services}

The first recorded paper studying the influence of sustainable agricultural practices on ecosystem services was published in the year 2001. The number of scientific publications addressing this topic modestly increased from $2007(n=1)$ to $2017(n=22)$, with the highest peak in $2016(n=37)$. These results show that this topic is an exponentially growing research field, but there are still few studies that have focused on it to date. This fact becomes more evident when we compare the published papers included in this review to the total number of publications on ecology and agronomy. The number of papers including the keyword "ecology" arithmetically grew from 35,037 in 2001 to 109,071 in 2017, while the ones including the keyword "agronomy" have also undergone arithmetic growth but remained very stable from approximately $2005(\mathrm{n}=12,471)$ to date $(\mathrm{n}=15,196)$ (Figure 2$)$.

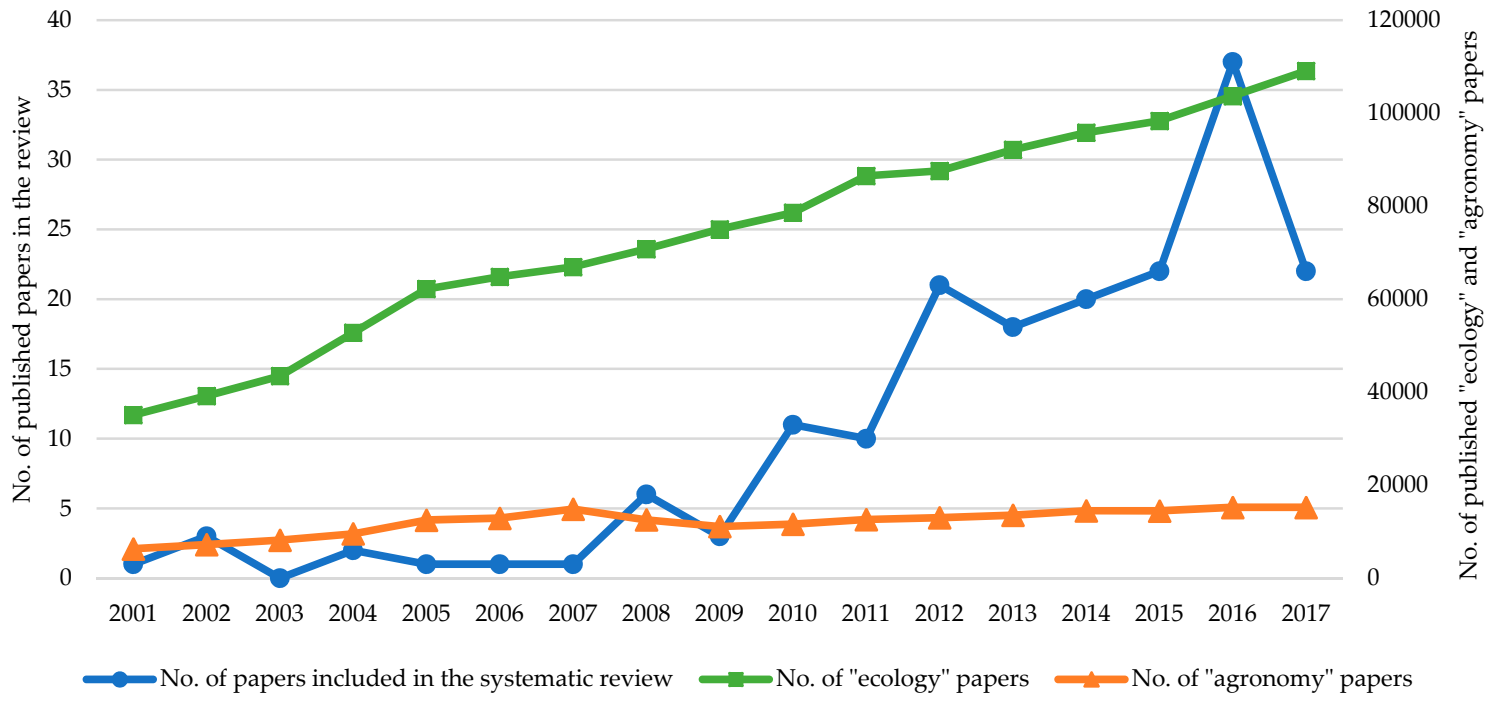

Figure 2. Temporal trends in scientific papers studying the influence of sustainable agricultural practices on ecosystem services (blue line) compared to the papers in ecology (green line) and agronomy (orange line). Data from Web of Science.

The study areas of the 179 selected papers were mainly located in Western Europe (23.2\%), North America (19.2\%) and Northern Europe (12.1\%; Figure 3), and most studies were conducted at a local $(37.4 \%)$ or regional $(36.9 \%)$ scale. The most common research areas specified for each paper in Web of Science were "Environmental Sciences \& Ecology" (34.0\%) and "Agriculture" (25.9\%), with most of the studies conducted by an interdisciplinary team $(72.6 \%)$ and using a quantitative approach $(78.8 \%)$, and biophysical methods (67.0\%) (Figure 4). 


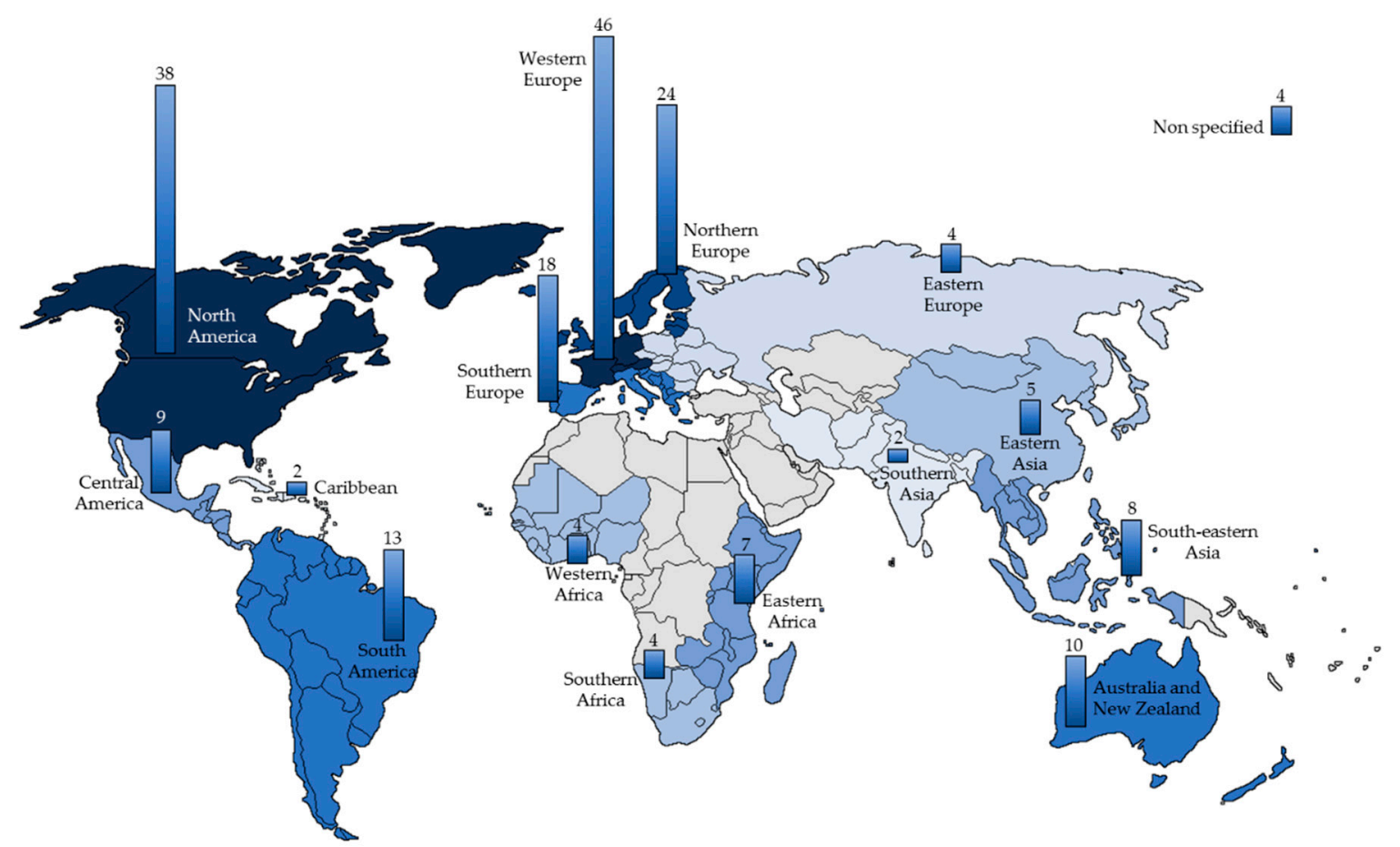

Figure 3. Geographical distribution of the study areas of the published papers included in the review. For each geographical area, the number of published papers is specified in columns. The non-specified column represents theoretical studies.

The crops most frequently studied were cereals (29.7\%), such as wheat, barley or rye; vegetables and melons (17.9\%), such as lettuce, pumpkins or onions; other crops (12.8\%), such as grasses, fiber crops or aromatic crops; fruits and nuts (10.3\%), such as blueberries, apples or almonds; and oilseed crops $(7.1 \%)$, such as soya beans, oil palms or rapeseed [42]. Few papers included the institutional context of the study area $(21.8 \%)$, and fewer than $50 \%$ of the papers considered benefits of the application of sustainable agricultural practices other than the ecological ones (43.0\%), included stakeholder participation in their analysis (37.4\%), or studied the effects of an agricultural transition to more sustainable agroecological systems (22.3\%). Likewise, 33.0\% of the papers included more than three of the ten agroecology elements defined by the FAO in some way, with the dimensions most similar to biophysical or ecological elements being the most frequently considered (resilience $(25.0 \%)$, efficiency $(22.9 \%)$, and diversity (19.7\%) of the systems). Other elements have received less attention, particularly those related to social-political elements (human and social values (3.8\%), circular economy (3.7\%), and culture and food traditions (3.4\%)) [32]. Only $10.7 \%$ of the papers included the terms "agroecology" or "agroecological", with "organic agriculture" (34.4\%) and "sustainable agriculture" (22.0\%) being the terms most frequently used to refer to the type of sustainable agricultural management (Figure 4). 

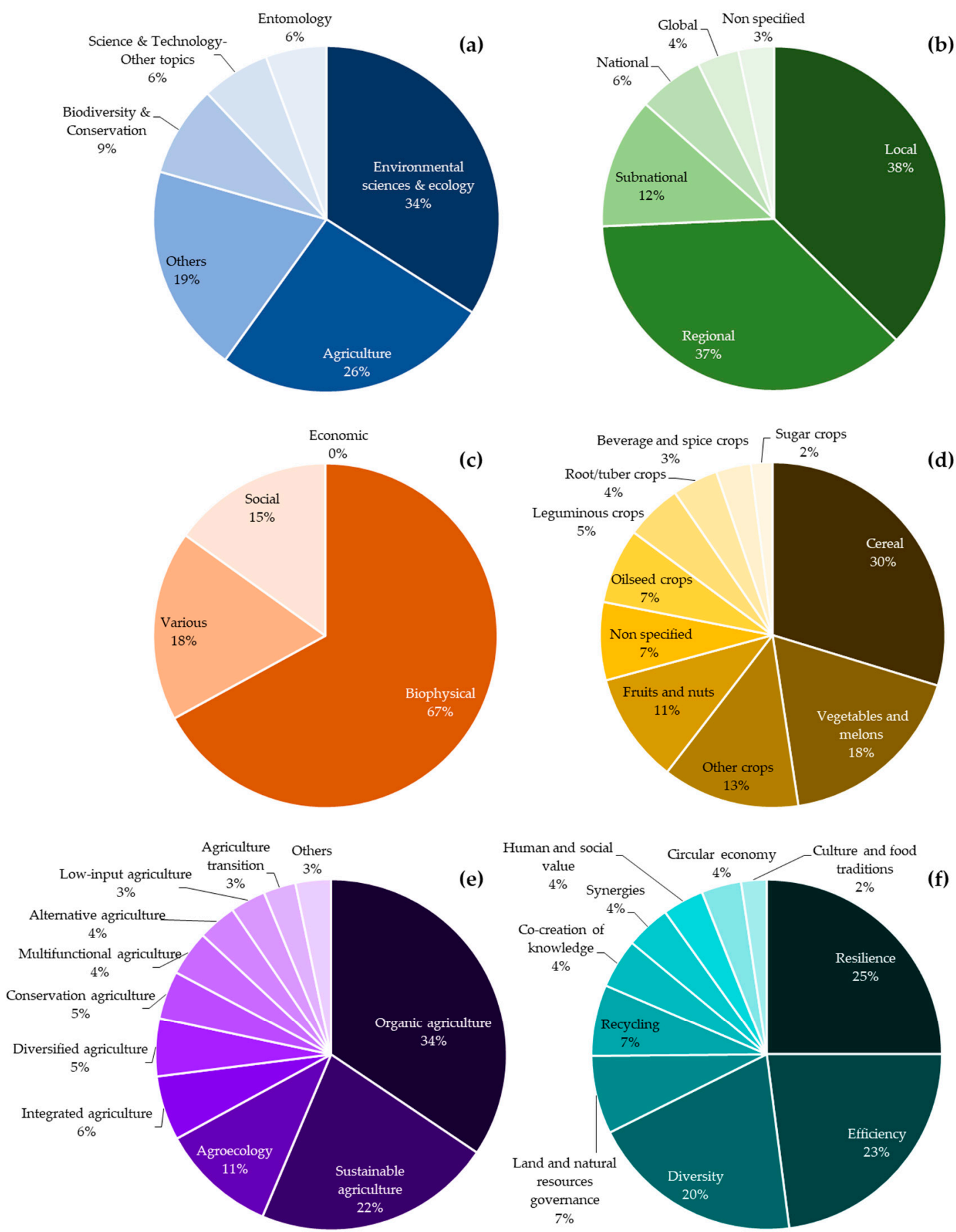

Figure 4. Percentage of reviewed papers characterized according to the (a) research areas specified in Web of Science, (b) spatial scale of analysis, (c) methodological approach, (d) studied crops, (e) terms used to refer to the type of agricultural management and (f) the FAO's elements of agroecology considered.

The number of papers that reported the existence of relationships between agricultural practices and ecosystem services and the number of papers that empirically analyzed those relationships were very similar (Figure 5). The five agricultural practices most frequently analyzed in the literature were no/natural fertilizers, no/natural pesticides, no/natural herbicides, complex landscapes and no/light tillage (Figure 5). The five ecosystem services most frequently studied were pest control, soil fertility, food, pollination and water flow maintenance/regulation (Figure 5). 


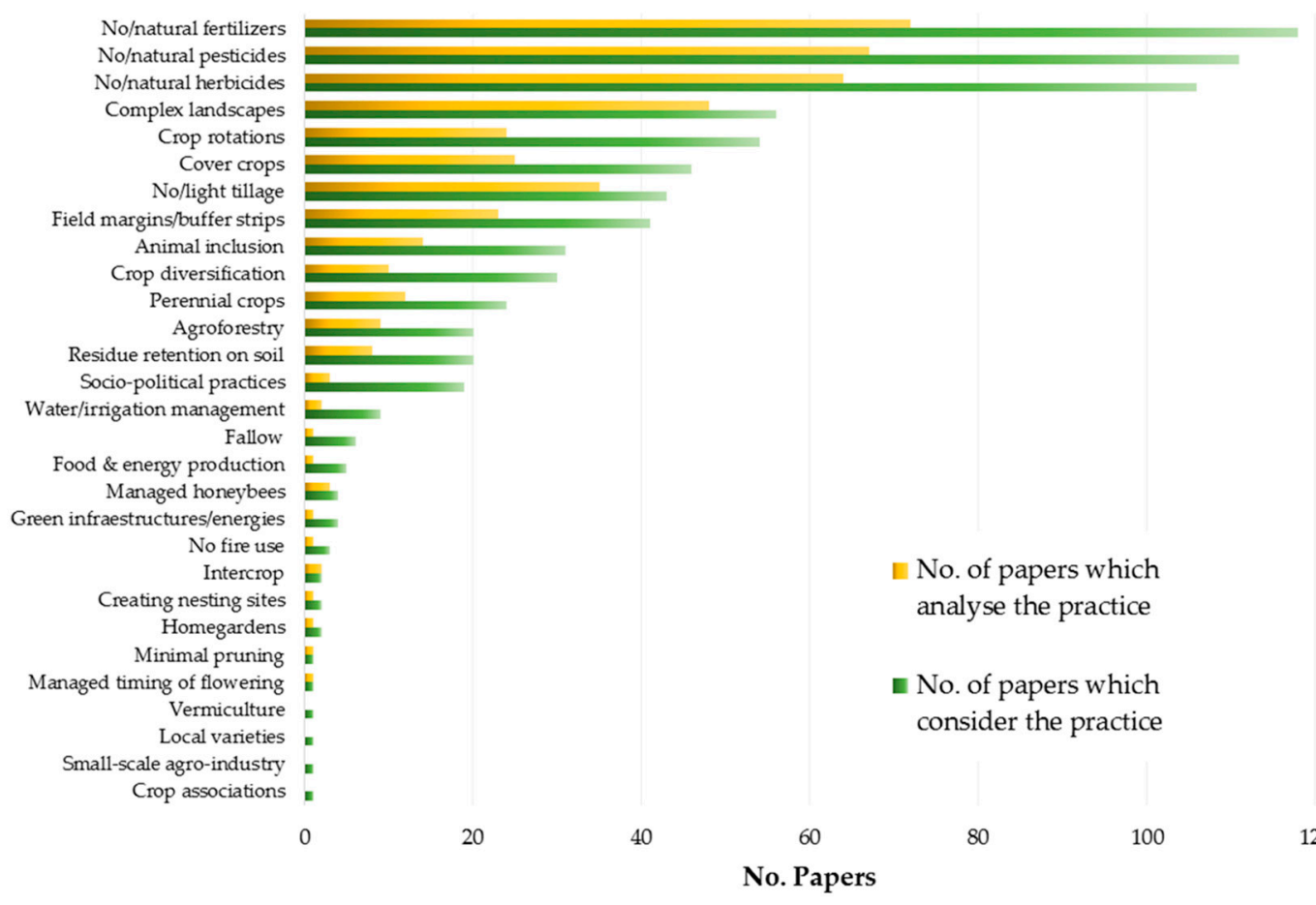

(a)

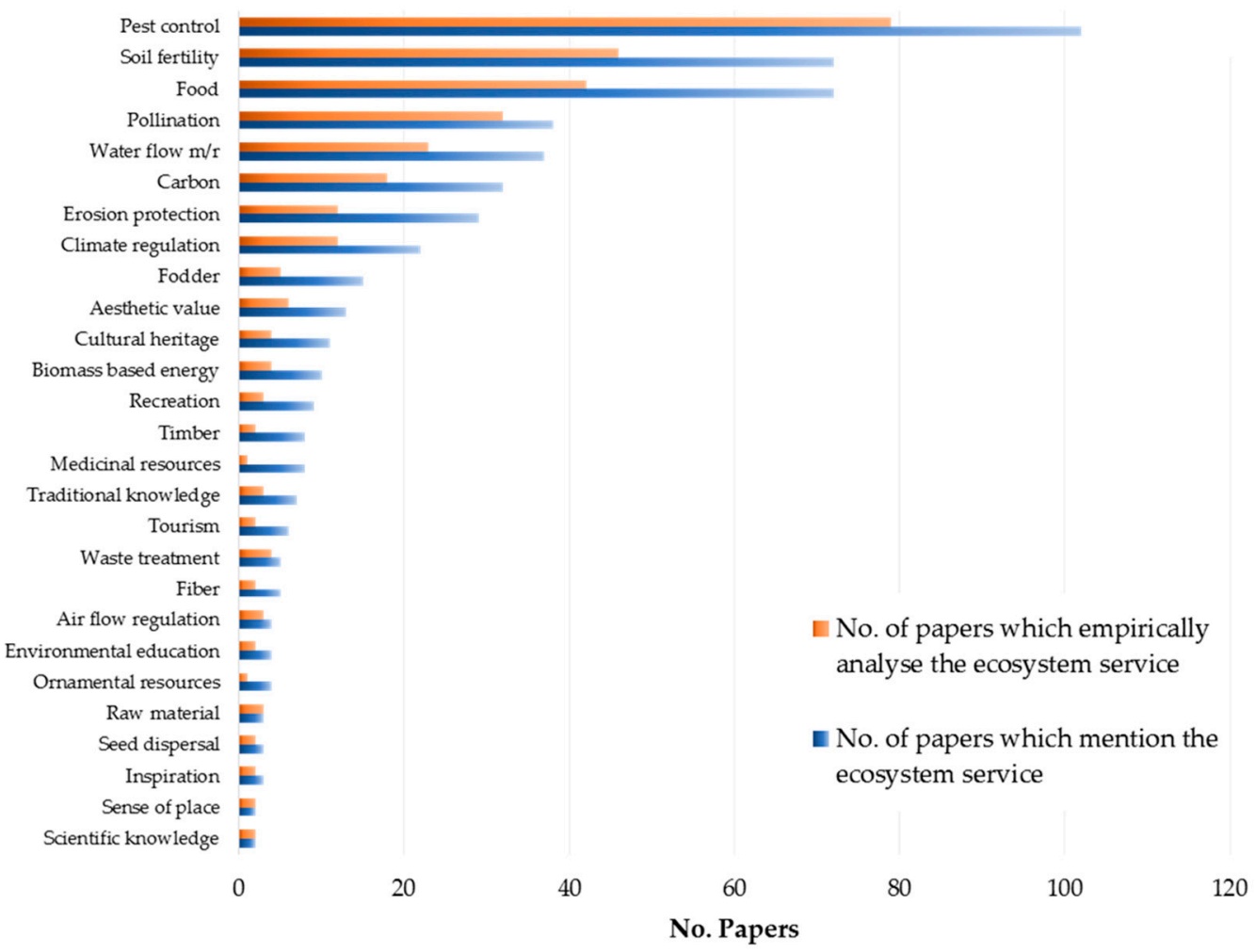

Figure 5. Number of papers that mention and empirically analyze (a) agricultural practices (green and yellow columns, respectively) and (b) ecosystem services (blue and orange columns, respectively). Both categories were named as they appeared in the reviewed papers. The practices named no/natural fertilizers, pesticides and herbicides refer to the nonuse of these inputs or the replacement of chemical inputs by natural or organic ones. 


\subsection{Linkages between Agroecological Practices and Ecosystem Services}

Overall, 3319 observations of empirically analyzed relationships between agricultural practices and ecosystem services were recorded in the sample (Figure 6). Of them, $54.2 \%$ found a positive effect of the practices on the ecosystem services, while $16.6 \%$ of the relationships were negative and $29.3 \%$ non-significant. Regulating services were the most frequently analyzed services $(96.6 \%$ of the papers analyzed at least one regulating service), followed by provisioning (31.3\%) and cultural services $(6.1 \%)$. When analyzing only the significant relationships between the agricultural practices and ecosystem services most frequently studied, there were 67 relationships between regulating services and agricultural practices, followed by 20 relationships between provisioning services and agricultural practices and 9 between cultural services and agricultural practices. Of the total number of these relationships ( $\mathrm{n}=96), 87$ had more than $50 \%$ positive observations, with 64 of them between agricultural practices and regulating services, 15 between agricultural practices and provisioning services, and eight between agricultural practices and cultural services. Only seven relationships had fewer than $50 \%$ positive observations, with four of them for provisioning services, two for regulating services and one for cultural services (Figure 7).

For regulating services, pest control, soil fertility and pollination had the greatest number of observations, while waste treatment, air flow regulation and seed dispersal were scarcely studied (Figure 6). The application of sustainable tillage practices and the nonuse of external inputs or agrochemicals (fertilizers, herbicides and pesticides) had more than $75 \%$ significant positive relationships with pest control, while more than $50 \%$ of the relationships between the presence of complex landscapes and pest control were positive. Regarding soil fertility, the nonuse of external inputs and the introduction of cover crops had more than $75 \%$ significant positive relationships with this ecosystem service in the reviewed literature. The presence of complex landscapes and field margins or buffer strips were identified as positive practices for pollination, with over $75 \%$ significant positive relationships reported between these practices and pollination (Figure 7).

Food and fodder were the main provisioning services studied, while there were no observations linking agricultural practices with genetic material, medicinal resources and ornamental resources (Figure 6). The application of crop rotations was positively related to food and fodder, with more than $50 \%$ significant positive relationships between crop rotations and food and $100 \%$ significant positive relationships between crop rotations and fodder. Sustainable tillage practices and the nonuse of external inputs were also relevant practices for the supply of food, with more than $50 \%$ significant positive relationships between them (Figure 7).

Aesthetic value was the cultural service most frequently analyzed, although no more than twenty observations between sustainable agricultural practices and aesthetic value were recorded (Figure 6). Every relationship between aesthetic value and the presence of complex landscapes, crop diversification and crop rotation were reported as positive in the literature. Sustainable tillage practices and the nonuse of external inputs had more than $75 \%$ significant positive relationships with aesthetic value, while the presence of field margins or buffer strips showed more than $50 \%$ significant negative relationships with this cultural ecosystem service in the literature (Figure 7). 


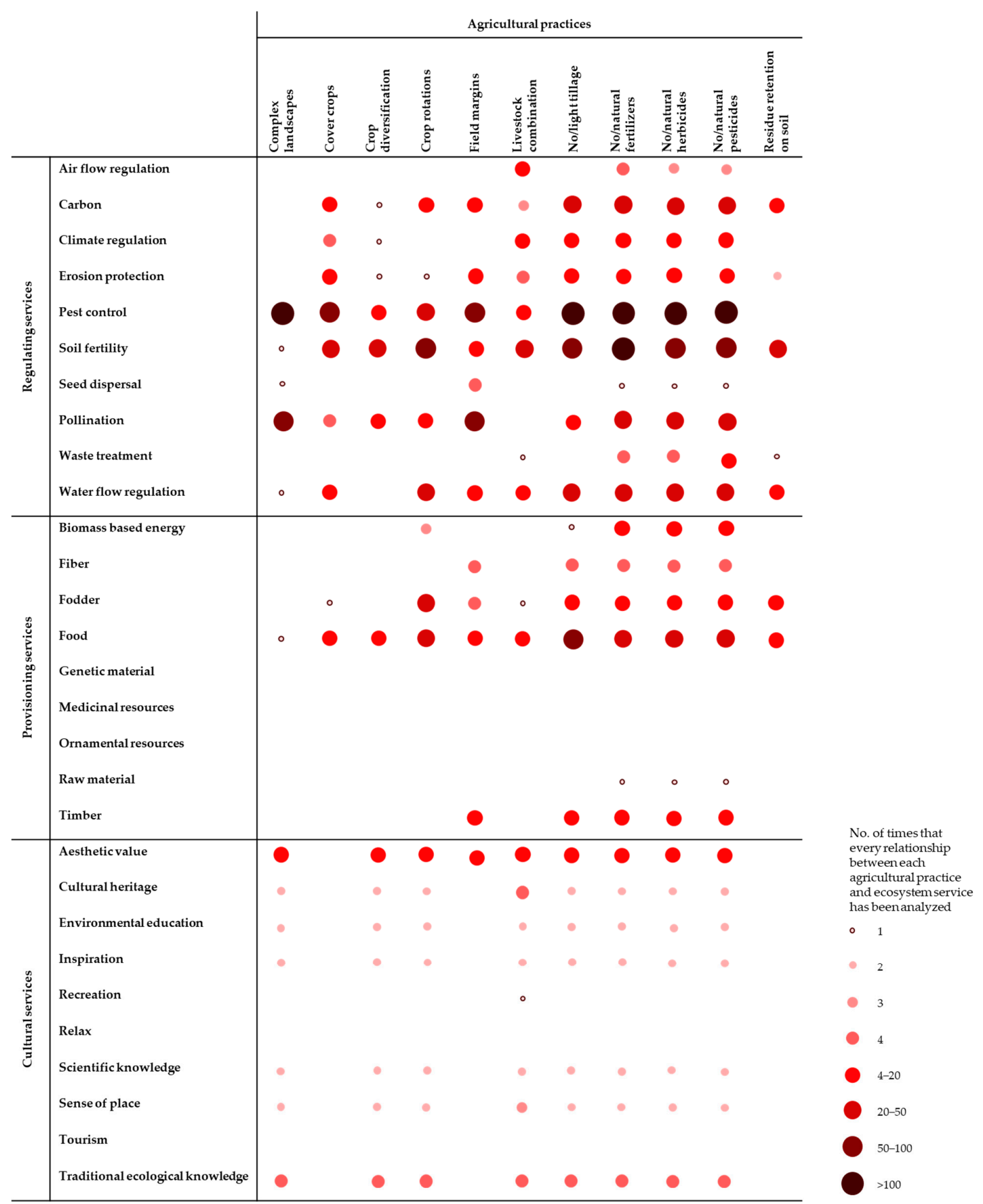

Figure 6. Number of relationships recorded between each ecosystem service and the most frequently analyzed agricultural practices. 


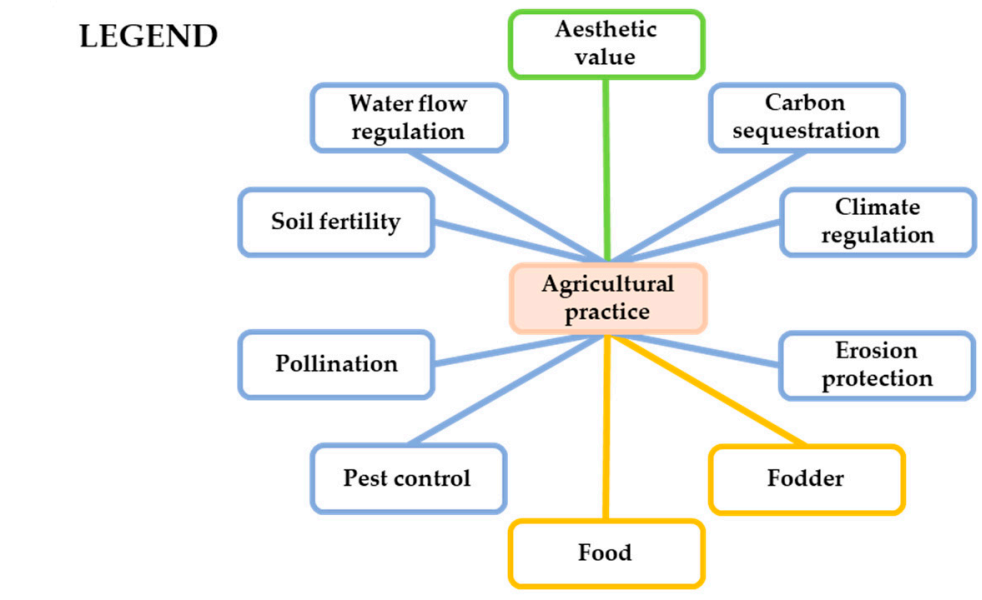

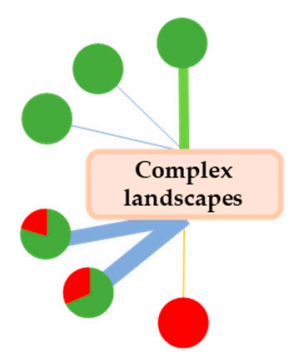
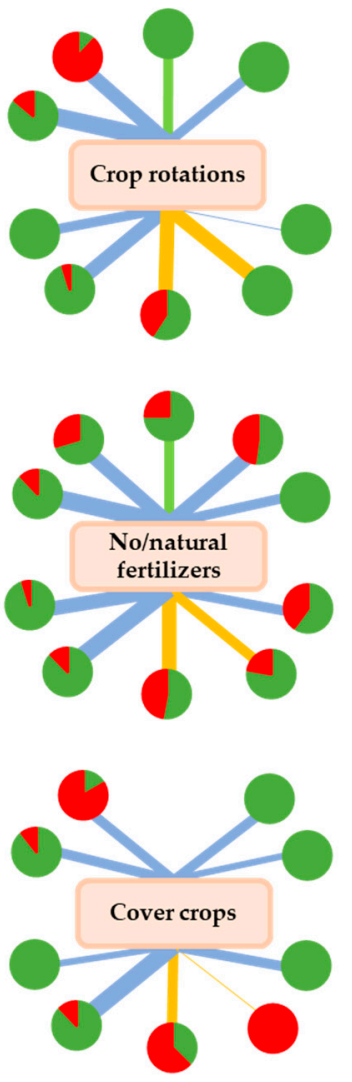
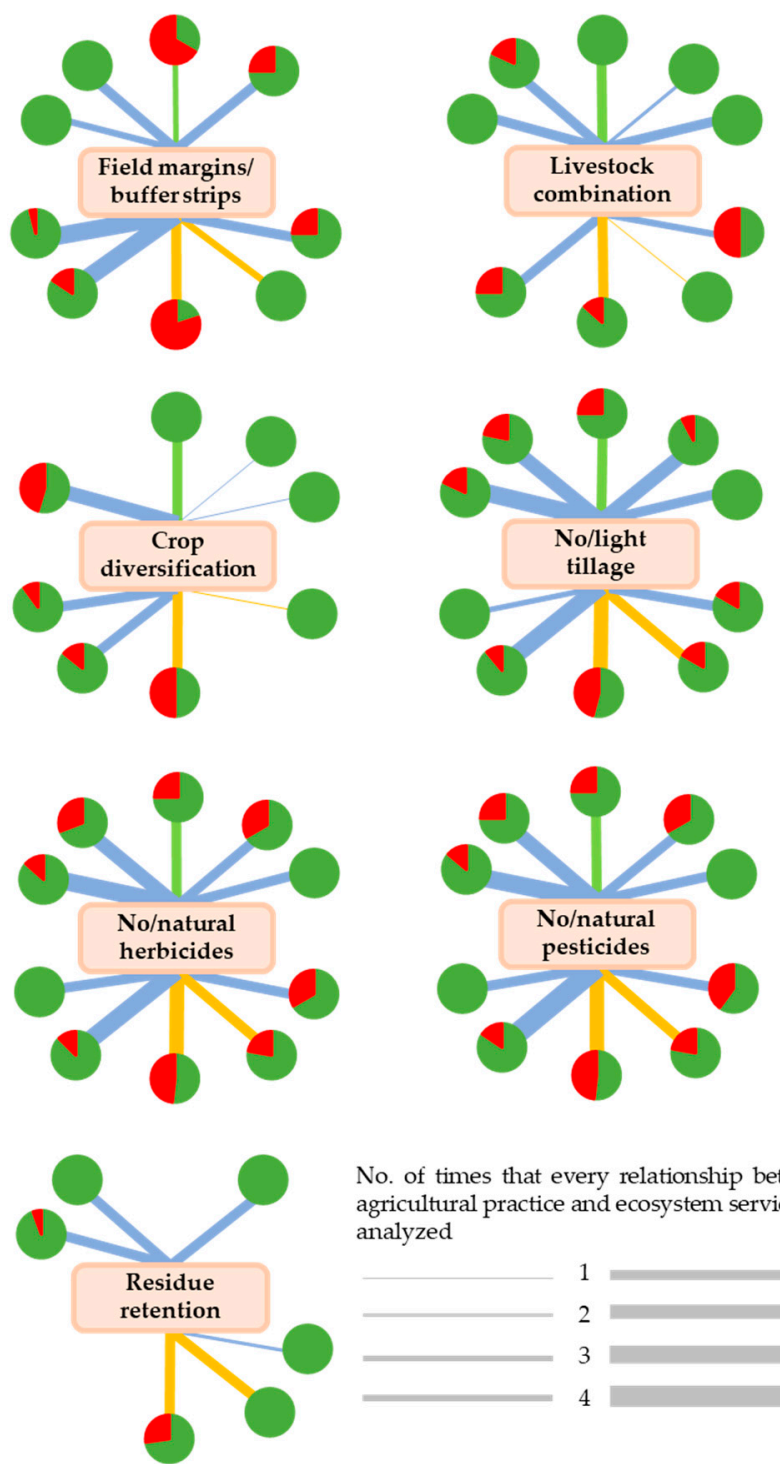

No. of times that every relationship between each agricultural practice and ecosystem service has been analyzed

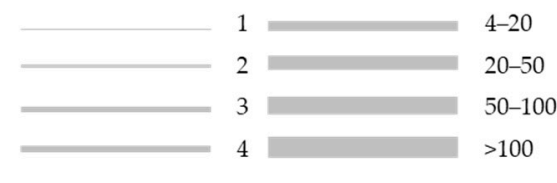

Figure 7. Significant relationships between the agricultural practices and ecosystem services most frequently studied. Line width represents the number of observations between each practice and ecosystem service. Pie charts represent the percentage of positive (green) and negative (red) observations for each relationship. Regulating services are represented in blue, provisioning services in yellow and cultural services in green. 


\subsection{Sets of Agroecological Practices Affecting Ecosystem Services}

The RDA indicates a significant linear relationship between agroecological practices and ecosystem services (Monte Carlo permutation test: Pseudo F $=0.072 ; p$-value $<0.0001$ ). The first two axes explained $85.61 \%$ of the total variance. The biplot of the RDA, representing the first two axes, is shown in Figure 8 (see Appendix B for the squared cosine value of the RDA variables).

The first axis of the RDA (66.09\% of the variance) revealed, based on the positive scores, an association of some ecosystem services highly related with biodiversity (e.g., pest control and pollination) with practices such as the promotion of complex landscapes, field margins and cover crops. The negative scores of the first axis revealed an association of soil fertility, food, fodder, and water regulation with agricultural practices such as crop rotations, residue retention on soils, livestock inclusion in farming practices and crop diversification.

The second axis of the RDA (19.52\% of the variance) revealed an association of pollination with field margins and crop diversification on the positive loads and an association of pest control mainly with cover crops on the negative loads (Figure 8).

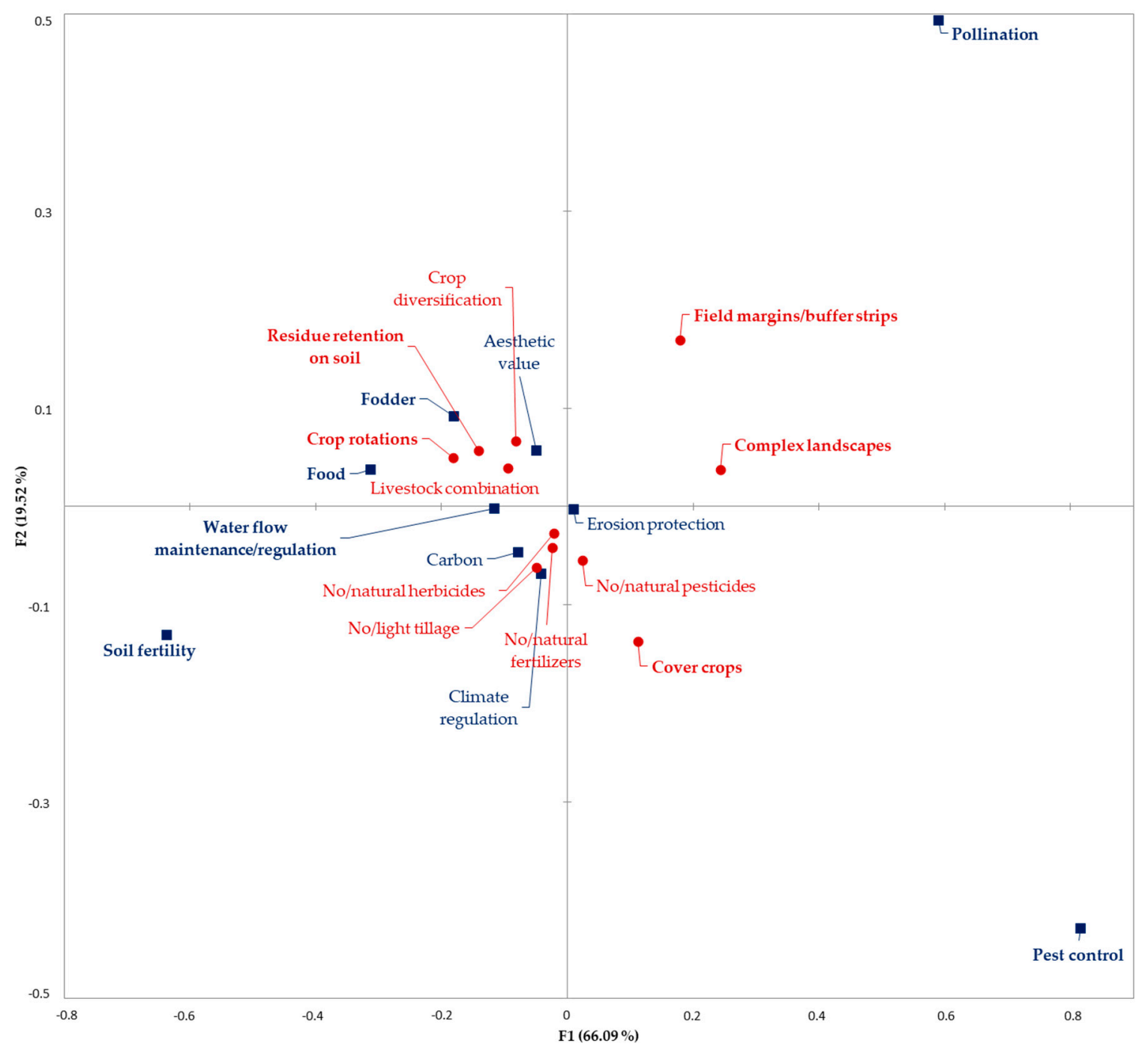

Figure 8. Biplots resulting from the redundancy analysis (RDA) performed to uncover the relationships between sustainable agricultural practices (red) and ecosystem services (blue). Bold text represents the agricultural practices and ecosystem services with higher scores. 


\section{Discussion}

\subsection{Research Gaps and Biases: Insights for Future Research}

The geographical distribution of the studies showed that most of the research conducted occurred in North America and Europe, while Central and South America, Africa and Asia only hosted 29.1\% of the studies. This situation highlights the need for increasing research on the effects of agricultural practices on ecosystem services in those understudied geographical areas, which also include the greatest number of countries around the world suffering from poverty and food insecurity [43]. For example, several studies acknowledge the contribution of agroecological practices in reducing poverty and food insecurity, increasing resilience, crop yields and ecosystem service supplies and satisfying economic, nutritional and social needs in Africa [44-47]. Similarly, as an Asian example, China's increasing population and use of intensive agricultural practices has severely degraded the ecosystem services supply in this country, a representative example being the hand pollination by humans due to the lack of pollinators in fruit crops in Maoxian County [30,48].

Another striking research gap in our literature review is the scarce use of the agroecology framework within the studies. It is noteworthy that the word "agroecology" or "agroecological" barely represents one-tenth of the keywords related to agricultural systems included in our search. Moreover, several studies including these keywords did not consider social or political issues but referred to agroecology as (1) the ecology of agroecosystems, (2) a synonym of agroecosystems or environmentally sustainable agriculture, or (3) did not even include the word "agroecology" in the body text, even if it was present in the abstract or keywords.

The social-political dimensions of agroecology in our review are underrepresented. On one hand, when analyzing the FAO's ten elements of agroecology, resilience was the element most frequently considered in the literature to link agroecological practices and ecosystem services. It was mainly understood as the capacity of agroecosystems to recover from pest or disease attacks through the use of sustainable practices. Efficiency was also frequently considered and was understood as the maintenance of or increase in crop production while reducing external inputs, such as fertilizers, herbicides and pesticides. Another FAO element frequently considered was diversity, with several practices being beneficial for its maintenance, such as intercropping, livestock combinations, or the exclusion of external inputs. On the other hand, dimensions directly related to social-political issues (e.g., human and social values, culture and food traditions, responsible governance, or circular and solidarity economies) were barely considered in the literature. We found a great difference in the number of studies analyzing regulating and cultural services, which reinforces the assumption that agroecological practices have mainly been studied because of their environmental and biophysical benefits, while few studies have analyzed their social benefits.

Ecological and social-cultural processes and the interactions between them are embedded in agroecosystems, so agroecological research should be adapted to each specific context and consider every existing relationship within it. In practice, few studies have utilized a holistic methodological approach when studying agroecosystems, since their multidimensionality has made them very complex objects of study. As a consequence, most studies have only focused on one or few dimensions of agroecology, with quantitative studies generally being oriented toward the analysis of the ecological-productive dimension and qualitative studies being focused on the analysis of social-political issues [49]. This, combined with the lack of a unified definition of the term "agroecology", might explain the existing gaps in our literature review regarding the inclusion of the agroecology framework. We acknowledge that the existence of some methodological limitations within our literature review also contributed to generate those gaps and biases. For example, the aim of our study resulted in a literature review focused on the productive dimension of the food chain supply, disregarding other dimensions such as commercialization or distribution and therefore contributing to the underrepresentation of the agroecology context within the literature surveyed. In any case, our search provided useful 
information regarding the effect of different sustainable agricultural practices (which can also be applied in agroecological systems) on the supply of ecosystem services.

\subsection{Relationships between Agroecological Practices and Ecosystem Services}

Previous studies have reviewed the relationships between agroecological or sustainable practices and ecosystem services [13,29,50-52], but, as far as we know, this is one of the first studies performing a systematic literature review on empirical research to identify positive relationships between key agroecological practices and ecosystem services. Our literature review showed that agroecological practices are generally more effective than conventional ones in supplying a wide variety of ecosystem services, suggesting the potential of agroecological practices to provide an environmentally sustainable alternative to conventional agricultural management. Several authors have also documented successful examples in which production and ecological benefits have been enhanced when adopting agroecological innovations [30]. Nevertheless, agroecology has not yet been widely disseminated. Starting a transition towards agroecological systems often requires deep knowledge on what practices should be adopted and when and how they should be applied to adapt farm management to specific biophysical conditions, such as the erosion potential and fertility of the farm soil, farm size, pedo-climatic conditions, pests and weeds, etc. [53-59]. Another possible explanation is that many other barriers inherent to the productive dimension have slowed down the spread of agroecological transitions, such as the need to include changes within the farming system to allow the application of some agroecological practices. Through the RDA analysis, we found several sets of ecosystem services associated with different types of agroecological practices that can be applied at different spatial scales and require different levels of system change. Some entail just changing a certain practice, others require changes at the farm scale, while others can be applied only through changes at the landscape scale. For example, the replacement of agrochemicals by organic fertilizers, herbicides and pesticides is easily applicable, while introducing biological pest control or organic fertilization requires a higher level of technological change [50]. Our results show that practices generally applied at the landscape level were related to ecosystem services that are more associated with biodiversity, while practices applied at the farm level were generally closer to soil and production services.

The use of cover crops and crop diversification are easily applicable practices, since they require low levels of system change, and they have thus been largely integrated into modern agriculture. This suggests that they may be good practices to start with to perform an agroecological transition [50]. Additionally, as several authors previously assessed [60-66], most of the reviewed studies showed that both practices were highly positive in terms of carbon sequestration, climate regulation, erosion protection, pest control and pollination services, which could be an additional incentive for farmers to introduce these practices in their fields.

Most of the papers included in our review studied the replacement of agrochemical inputs by organic inputs, finding positive effects on soil fertility and climate regulation by applying organic fertilizers and a reduction in pest outbreaks and weed infestations by applying organic herbicides and pesticides. One reason that might explain the high number of studies including the nonuse of external inputs or agrochemicals is that those practices are mandatory in organic agriculture, which was the most studied system in our literature review $[67,68]$.

Crop rotations and the introduction of field margins or flower buffer strips are practices that must be applied at the farm scale and require a medium level of system change [50]. On one hand, crop rotations are frequently applied in combination with cover crops and crop diversification practices. Thus, the application of crop rotations has also been positively associated with carbon sequestration, climate regulation, erosion protection, pest control, and pollination services. Crop rotations have also been identified in the reviewed literature as positive for soil fertility, fodder and aesthetic value services. The downside is that crop rotation requires a higher level of system change and crop knowledge, so it would be advisable to start with practices that are more easily applicable, such as the use of cover crops, 
before introducing crop rotations. On the other hand, the introduction of field margins or flower buffer strips was shown to greatly affect many ecosystem services, such as pollination, soil fertility, water flow management, pest control, erosion protection, carbon sequestration and fodder, in a positive way in our literature review. In contrast, as other studies previously revealed [69-71], we identified that the major constraint of field margins is that their application may result in lower yields when compared to less sustainable practices since their introduction frequently implies a reduction in the farming area.

Reduced tillage or no tillage were found to be key practices that require a medium to high level of system change since their application relies on the usage of specific machinery, and they should be combined with other practices, such as crop rotation or intercropping, to avoid weed infestation [50]. In addition to the risk of weed infestation, our study corroborates others that found [72-75] a positive effect of tillage management practices on many other ecosystem services, such as carbon sequestration, climate regulation, erosion protection, pest control, pollination, soil fertility, water flow management, fodder and aesthetic value.

The practices that are harder to apply are those that require action at the landscape level, such as the presence of complex landscapes, which positively affected pollination, soil fertility and water flow management services in our literature review. As also occurred with field margins, the integration of complex landscapes within agroecosystems may result in lower yields, which, combined with its practical difficulties, has resulted in the low application of this practice. Nevertheless, our results revealed that it was the fourth most frequently studied practice. An explanation for this fact could be that most of the reviewed literature analyzing the effects of complex landscapes on ecosystem services did not include studies in which landscape elements had been managed or integrated but took as study areas farms that were already surrounded by natural or semi-natural habitats. Another practice that necessitates a redesign of the whole farming system for its application is the introduction of livestock within farming systems [50]. Despite its management constraints, livestock and crop combination has been identified as a highly beneficial practice for enhancing soil fertility, food and pest control services. Additionally, the introduction of livestock facilitates the replacement of chemical fertilizers by animal manure [50].

\subsection{Management Implications of the Agroecological Transition}

Feeding the increasing world population while preserving the correct functioning of ecosystems has become a challenge under the current patterns of global change. Agroecology emerged as a transformative approach to address this challenge, fostering the application of sustainable agricultural practices and considering every element of the agri-food chain to promote ecologically sustainable and socially fair agriculture worldwide. Our literature review suggests the effectiveness of agroecological practices for supplying a wide variety of ecosystem services.

Opponents of agroecology argue that the only way to address the current and future demand of food worldwide is to maximize crop yields through intensive practices or high technology [14-17]. Our study showed that the presence of complex landscapes, the inclusion of field margins and the application of cover crops often result in negative effects on crop yields when compared to less sustainable practices. Nevertheless, every other practice analyzed in the literature had a higher percentage of observations reporting positive effects on the food supply. Additionally, although some agroecological practices may result in lower yields, the enhancement of crop quality when applying these production techniques has been frequently addressed [76-78].

The proposed scheme for the progressive introduction of agroecological practices only represents an example of how an agroecological transition could be performed from the productive dimension. As mentioned above, each agroecosystem has its own ecological and social-political particularities, so the transition must be adapted to each specific area. Therefore, to achieve a successful agroecological transition, farmers should begin by introducing practices with low requirement levels of system change to progressively introduce more complex practices that entail working at the landscape scale 
and often require agreements among different stakeholders, through collective management, to be implemented [50,59].

The multidimensional and complex nature of agroecosystems implies challenges for the spread of agroecology not only from the productive dimension but also from all other dimensions of the food chain supply [79]. In this way, farmer associations, organizations and movements are key elements to horizontally spread agroecological knowledge from farmer to farmer, favoring the transition of larger areas to agroecological systems $[59,80]$. However, the spread of agroecological knowledge is not only the responsibility of farmers or decentralized organizations. Government policies, public and private institutions, non-governmental organizations, researchers, markets, agroecological organizations, consumers and the media $[22,57,59,79,81]$ also play a crucial role in compiling and disseminating agroecological knowledge $[22,57,80]$. To this extent, agroecology (or at least some of its principles) has recently begun to be included in several public policies, global agencies, universities and scientific knowledge organizations; however, it is difficult to find a unified definition of agroecology, and, as shown by our review, there is a large diversity of concepts related to developing sustainable practices. However, even though international forums and symposiums [30,81] have recognized agroecology as an intrinsic part of the food sovereignty proposal, agroecology is absent or underrepresented in the public policies of the European Union (EU), such as the Rural Development Policy of the Common Agricultural Policy. EU policies offer farm subsidies or funding opportunities for farmers that are mainly focused on producing in a more ecologically friendly way but disregarding social-economic and cultural determinants [82]. Such policies are key elements in the spread of agroecology, since incentives (economic, technical advice, acknowledgement and visibility, etc.) to producers are essential to foster the application of certain practices or acquire specific materials [59]. In this way, our literature review could be a helpful tool for designing the European Agri-Environmental Schemes and prioritizing the recommended practices that should be included in the Rural Development Policy.

Feeding the increasing world population while preserving the correct functioning of ecosystems has become a challenge under the current patterns of global change. Agroecology emerged as a transformative approach to address this challenge, fostering the application of sustainable agricultural practices and considering every element of the agri-food chain to promote an ecologically sustainable and socially fair agriculture worldwide. Our literature review proved the effectiveness of agroecological practices for supplying a wide variety of ecosystem services.

Supplementary Materials: The following are available online at http:/ / www.mdpi.com/2071-1050/10/12/4339/ s1, Table S1: Complete list of attributes compiled in our literature review; Document S1: Complete list of studies included in our literature review.

Author Contributions: Conceptualization, S.P.-C., M.G.-L. and J.A.G.; Methodology, S.P.C., M.G.-L. and J.A.G.; Formal Analysis, S.P.-C.; Investigation, S.P.-C.; Resources, M.G.-L.; Data Curation, S.P.-C.; Writing-Original Draft Preparation, S.P.-C.; Writing-Review \& Editing, M.G.-L. and J.A.G.; Visualization, S.P.-C.; Project Administration, M.G.-L. and J.A.G.

Funding: Sara Palomo-Campesino was funded by a grant from the Spanish National Institute for Agriculture and Food Research and Technology, co-funded by the Social European Fund (FPI-INIA). Marina García-Llorente was funded by a postdoctoral grant from the Spanish National Institute for Agriculture and Food Research and Technology co-funded by the Social European Fund (Doc-INIA CCAA); and the IMIDRA research project: Assessment of Ecosystem Services provided by Agroecosystems (FP16 ECO).

Acknowledgments: We acknowledge Federica Ravera for her knowledge and assistance in the methodology design. We also acknowledge the reviewers for their thorough evaluation of the manuscript and their positive feedback.

Conflicts of Interest: The authors declare no conflict of interest. 


\section{Appendix A}

Table A1. Complete list of keywords used in the systematic literature review.

\begin{tabular}{|c|c|}
\hline & Keywords \\
\hline $\begin{array}{l}\text { Sustainable } \\
\text { management }\end{array}$ & 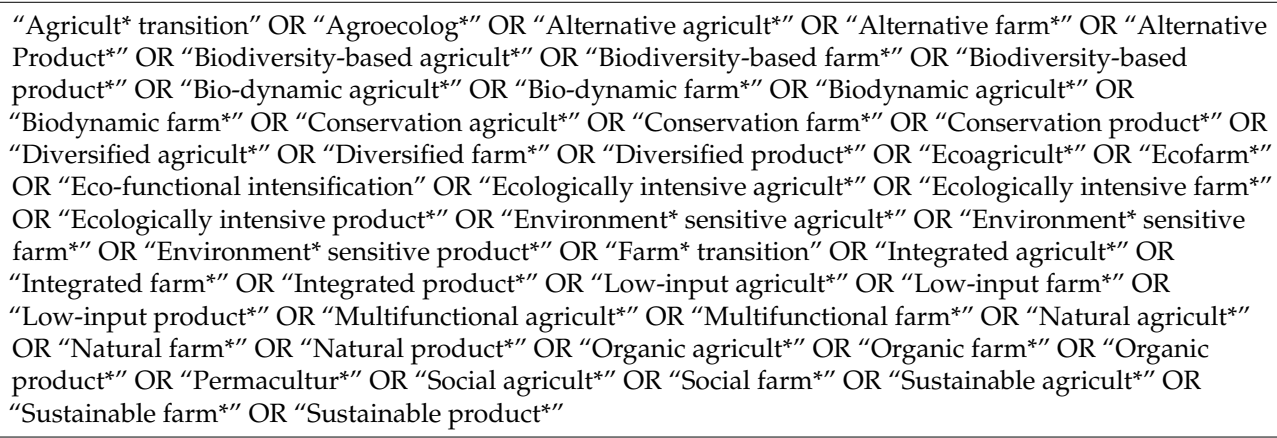 \\
\hline $\begin{array}{l}\text { Ecosystem } \\
\text { services' } \\
\text { framework }\end{array}$ & 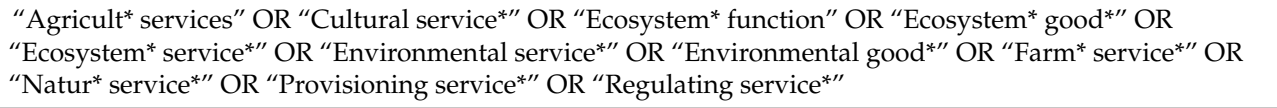 \\
\hline $\begin{array}{l}\text { Ecosystem } \\
\text { services }\end{array}$ & 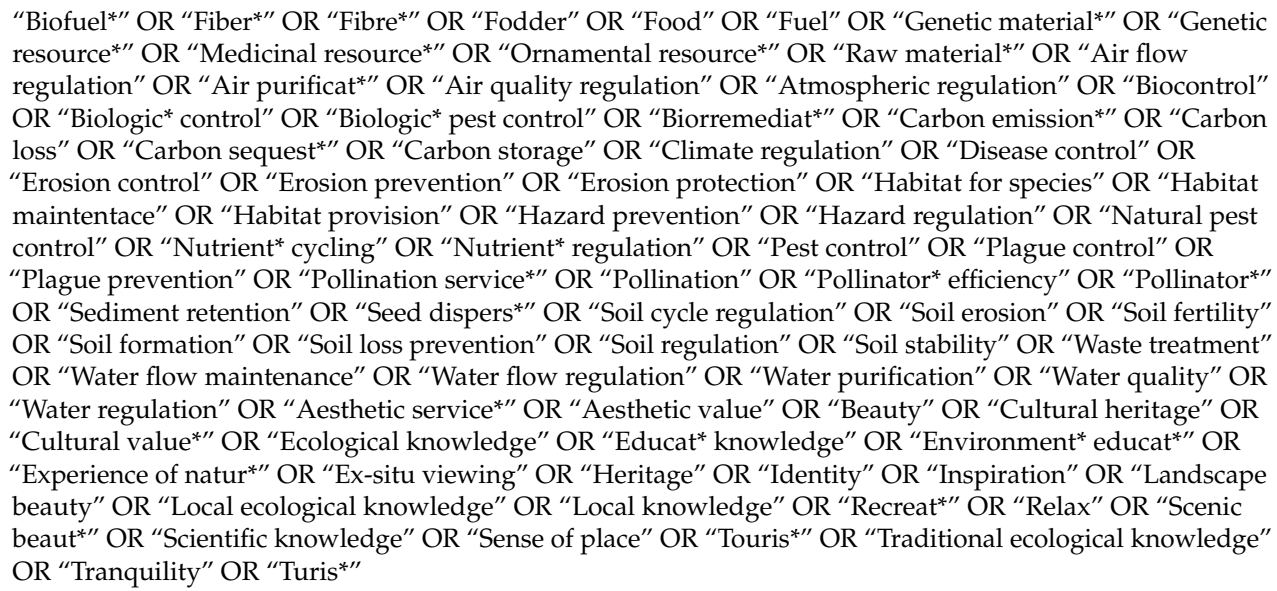 \\
\hline
\end{tabular}

\section{Appendix B}

Table A2. Scores and squared cosines of the RDA response variables.

\begin{tabular}{ccccc}
\hline & \multicolumn{2}{c}{ Scores } & \multicolumn{2}{c}{ Squared Cosines } \\
\hline & F1 & F2 & F1 & F2 \\
Fodder & -0.180 & 0.091 & 0.396 & 0.102 \\
Food & -0.313 & 0.037 & 0.788 & 0.011 \\
Pest control & 0.816 & -0.429 & 0.777 & 0.215 \\
$\quad$ Carbon & -0.079 & -0.046 & 0.136 & 0.047 \\
sequestration & 0.010 & -0.003 & 0.007 & 0.001 \\
Erosion protection & -0.673 & -0.130 & 0.792 & 0.033 \\
Soil fertility & -0.041 & -0.068 & 0.052 & 0.141 \\
Climate regulation & -0.116 & -0.002 & 0.195 & 0.000 \\
Water flow & 0.590 & 0.494 & 0.572 & 0.401 \\
regulation & -0.050 & 0.056 & 0.067 & 0.086 \\
Pollination & & & &
\end{tabular}


Table A3. Scores of the RDA explanatory variables.

\begin{tabular}{ccc}
\hline & \multicolumn{2}{c}{ Scores } \\
\hline No/natural fertilizers & F1 & F2 \\
No/natural pesticides & 0.024 & -0.042 \\
No/natural herbicides & -0.021 & -0.055 \\
No/light tillage & -0.049 & -0.027 \\
Crop rotations & -0.182 & -0.062 \\
Field margins/buffer strips & 0.179 & 0.050 \\
Complex landscapes & 0.244 & 0.169 \\
Cover crops & 0.112 & 0.037 \\
Livestock combination & -0.095 & 0.137 \\
Crop diversification & -0.082 & 0.066 \\
Residue retention on soil & -0.142 & 0.057 \\
\hline
\end{tabular}

\section{References}

1. Asner, G.P.; Elmore, A.J.; Olander, L.P.; Martin, R.E.; Harris, A.T. Grazing systems, ecosystem responses, and global change. Annu. Rev. Environ. Resour. 2004, 29, 261-299. [CrossRef]

2. The World Bank. Agricultural Land (\% of Land Area). Available online: https://data.worldbank.org/ indicator / AG.LND.AGRI.ZS?end=2015\&start=1961 (accessed on 6 June 2018).

3. Borlaug, N.E. The Green Revolution: For bread and peace. Bull. Atom. Sci. 1971, 27, 6-48. [CrossRef]

4. Matson, P.A.; Parton, W.J.; Power, A.G.; Swift, M.J. Agricultural intensification and ecosystem properties. Science 1997, 277, 504. [CrossRef] [PubMed]

5. Tilman, D. Global environmental impacts of agricultural expansion: The need for sustainable and efficient practices. Proc. Natl. Acad. Sci. USA 1999, 96, 5995-6000. [CrossRef] [PubMed]

6. Green, R.E.; Cornell, S.J.; Scharlemann, J.P.W.; Balmford, A. Farming and the fate of wild nature. Science 2005, 307, 550-555. [CrossRef] [PubMed]

7. Tscharntke, T.; Clough, Y.; Wanger, T.C.; Jackson, L.; Motzke, I.; Perfecto, I.; Vandermeer, J.; Whitbread, A. Global food security, biodiversity conservation and the future of agricultural intensification. Biol. Conserv. 2012, 151, 53-59. [CrossRef]

8. Amanor, K.S. The new frontier: Farmer's response to land degradation-A West African study. In Revisiting Sustainable Development, 1st ed.; United Nations Research Institute for Social Development (UNRISD): Geneva, Switzerland, 2015; p. 180. ISBN 978-9-290-85094-6.

9. United Nations Research Institute for Social Development. Social development and the International Development Strategy. In Revisiting Sustainable Development, 1st ed.; United Nations Research Institute for Social Development (UNRISD): Geneva, Switzerland, 2015; p. 19. ISBN 978-9-290-85094-6.

10. Pearse, A. Seeds of plenty, seeds of want: Social and economic implications of the Green Revolution. In Revisiting Sustainable Development, 1st ed.; United Nations Research Institute for Social Development (UNRISD): Geneva, Switzerland, 2015; pp. 160, 174. ISBN 978-9-290-85094-6.

11. Therond, O.; Duru, M.; Roger-Estrade, J.; Richard, G. A new analytical framework of farming system and agriculture model diversities. A review. Agron. Sustain. Dev. 2017, 37, 21. [CrossRef]

12. United Nations, Department of Economic and Social Affairs, Population Division. World Population Prospects: The 2015 Revision, Key Findings and Advance Tables, 2015 (Working Paper No. ESA/P/WP.241). Available online: https:/ / www.popline.org/node/ 639412 (accessed on 19 November 2018).

13. Kremen, C.; Miles, A. Ecosystem services in biologically diversified versus conventional farming systems: Benefits, externalities, and trade-offs. Ecol. Soc. 2012, 17, 40. [CrossRef]

14. Borlaug, N. Ending world hunger. The promise of biotechnology and the threat of antiscience zealotry. Plant. Physiol. 2000, 124, 487-490. [CrossRef] [PubMed]

15. Phipps, R.H.; Park, J.R. Environmental benefits of genetically modified crops: Global and European perspectives on their ability to reduce pesticide use. J. Anim. Feed. Sci. 2002, 11, 1-18. [CrossRef]

16. Godfray, H.C.J.; Beddington, J.R.; Crute, I.R.; Haddad, L.; Lawrence, D.; Muir, J.F.; Pretty, J.; Robinson, S.; Thomas, S.M.; Toulmin, C. Food security: The challenge of feeding 9 billion people. Science 2010, 327, 812-818. [CrossRef] [PubMed] 
17. Tester, M.; Langridge, P. Breeding technologies to increase crop production in a changing world. Science 2010, 327, 818-822. [CrossRef] [PubMed]

18. Tilman, D.; Cassman, K.G.; Matson, P.A.; Naylor, R.; Polasky, S. Agricultural sustainability and intensive production practices. Nature 2002, 418, 671-677. [CrossRef] [PubMed]

19. Jackson, L.E.; Pascual, U.; Hodgkin, T. Utilizing and conserving biodiversity in agricultural landscapes. Agric. Ecosyst. Environ. 2007, 121, 196-210. [CrossRef]

20. Scherr, S.; McNeely, J.A. Biodiversity conservation and agricultural sustainability: Towards a new paradigm of "ecoagriculture" landscapes. Phil. Trans. R. Soc. 2008, 363, 477-494. [CrossRef] [PubMed]

21. Perfecto, I.; Vandermeer, J. The agroecological matrix as alternative to the land-sparing/agriculture intensification model. Proc. Natl. Acad. Sci. USA 2010, 107, 5786-5791. [CrossRef] [PubMed]

22. Altieri, M.A.; Funes-Monzote, F.R.; Petersen, P. Agroecologically efficient agricultural systems for smallholder farmers: Contributions to food sovereignity. Agron. Sustain. Dev. 2012, 32, 1-13. [CrossRef]

23. Wezel, A.; Bellon, S.; Doré, T.; Francis, C.; Vallod, D.; David, C. Agroecology as a science, a movement and a practice. Agron. Sustain. Dev. 2009, 29, 503-515. [CrossRef]

24. Altieri, M.A. Agroecology: The Science of Sustainable Agriculture, 2nd ed.; CRC Press: Boca Raton, FL, USA, 1995; ISBN 9780429964015.

25. Altieri, M.A. Agroecology: The science of natural resource management for poor farmers in marginal environments. Agric. Ecosyst. Environ. 2002, 93, 1-24. [CrossRef]

26. Francis, C.; Lieblein, G.; Gliessman, S.; Breland, T.A.; Creamer, N.; Harwood, R.; Salomonsson, L.; Helenius, J.; Rickerl, D.; Salvador, R.; et al. Agroecology: The ecology of food systems. J. Sustain. Agric. 2003, 22, 99-118. [CrossRef]

27. Gliessman, S. Agroecology: Growing the roots of resistance. Agroecol. Sustain. Food Syst. 2013, 37, $19-31$.

28. Gliessman, S. Defining agroecology. Agroecol. Sustain. Food Syst. 2018, 42, 599-600. [CrossRef]

29. Migliorini, P.; Wazel, A. Converging and diverging principles and practices of organic agriculture regulations and agroecology. A review. Agron. Sustain. Dev. 2017, 37, 63. [CrossRef]

30. FAO. Agroecology for food security and nutrition. In Proceedings of the FAO International Symposium, Rome, Italy, 18-19 September 2014; FAO: Rome, Italy, 2015.

31. FAO. Food and Agriculture: Driving Action Across the 2030 Agenda for Sustainable Development. Available online: http:/ / www.fao.org/3/a-i7454e.pdf (accessed on 13 June 2018).

32. FAO. The 10 elements of Agroecology: Guiding the Transitions to Sustainable Food and Agricultural Systems. Available online: http:/ / www.fao.org/3/19037EN/i9037en.pdf (accessed on 13 June 2018).

33. Milan Urban Food Policy Pact. Available online: http://www.milanurbanfoodpolicypact.org/wp-content/ uploads/2016/06/Milan-Urban-Food-Policy-Pact-EN.pdf (accessed on 13 June 2018).

34. Agroecology Europe. A European Association for Agroecology. Available online: http://www.agroecologyeurope.org (accessed on 24 August 2018).

35. Helliwell, D.R. Valuation of wildlife resources. Reg. Stud. 1969, 3, 41-47. [CrossRef]

36. Ehrlich, P.R.; Mooney, H.A. Extinction, substitution, and ecosystem services. Bioscience 1983, 4, $248-254$. [CrossRef]

37. Peeters, A.; Dendoncker, N.; Jacobs, S. Enhancing ecosystem services in Belgian agriculture through agroecology: A vision for a farming with a future. Ecosyst. Ser. 2014, 285-304.

38. MEA (Millennium Ecosystem Assessment). Ecosystems and Human Well-Being: Synthesis; Inland Press: Washington, DC, USA, 2005; ISBN 1-59726-040-1.

39. Zhang, W.; Ricketts, T.H.; Kremen, C.; Carney, K.; Swinton, S.M. Ecosystem services and dis-services to agriculture. Ecol. Econ. 2007, 64, 253-260. [CrossRef]

40. Swinton, S.M.; Lupi, F.; Robertson, G.P.; Hamilton, S.K. Ecosystem services and agriculture: Cultivating agricultural ecosystems for diverse benefits. Ecol. Econ. 2007, 64, 245-252. [CrossRef]

41. Shamseer, L.; Moher, D.; Clarke, M.; Ghersi, D.; Liberati, A.; Petticrew, M.; Shekelle, P.; Stewart, L.A. Preferred reporting items for systematic review and meta-analysis protocol (PRISMA-P) 2015: Elaboration and explanation. BMJ 2015, 349, g7647. [CrossRef] [PubMed]

42. FAO. Classification of Crops. Available online: http://www.fao.org/fileadmin/templates/ess/documents/ world_census_of_agriculture/appendix3_r7.pdf (accessed on 22 August 2018).

43. World Food Programme. Hunger Map 2017. Available online: https://www.wfp.org/content/2017-hungermap?_ga=2.159078586.1099849848.1535698142-1157454347.1532341998 (accessed on 23 July 2018). 
44. Snapp, S.S.; Blackie, M.J.; Gilbert, R.A.; Bezner-Kerr, R.; Kanyama-Phiri, G.Y. Biodiversity can support a greener revolution in Africa. Proc. Natl. Acad. Sci. USA 2012, 107, 20840-20845. [CrossRef] [PubMed]

45. Isaacs, K.B.; Snapp, S.S.; Chung, K.; Waldman, K.B. Assessing the value of diverse cropping systems under a new agricultural policy environment in Rwanda. Food Sec. 2016, 8, 491-506. [CrossRef]

46. Makate, C.; Makate, M.; Mango, N. Sustainable agriculture practices and livelihoods in pro-poor smallholder farming systems in southern Africa. Afr. J. Sci. Technol. Innov. Dev. 2017, 9, 269-279. [CrossRef]

47. Naab, J.B.; Mahama, G.Y.; Yahaya, I.; Prasad, P.V.V. Conservation agriculture improves soil quality, crop yield, and incomes of smallholder farmers in North Western Ghana. Front. Plant Sci. 2017, 8, 996. [CrossRef] [PubMed]

48. Intergovernmental Science-Policy Platform on Biodiversity and Ecosystem Services (IPBES). The Assessment Report of the Intergovernmental Science-Policy Platform on Biodiversity and Ecosystem Services on Pollinators, Pollination and Food Production; Secretariat of the Intergovernmental Science-Policy Platform on Biodiversity and Ecosystem Services: Bonn, Germany, 2017; p. 61. ISBN 978-92-807-3567-3.

49. Álvarez-Salas, L.M.; Polanco-Echeverry, D.N.; Ríos-Osorio, L. Reflexiones acerca de los aspectos epistemológicos de la agroecología. Cuadernos de Desarrollo Rural. 2014, 11, 55-74. [CrossRef]

50. Wezel, A.; Casagrande, M.; Celette, F.; Vian, J.-F.; Ferrer, A.; Peigné, J. Agroecological practices for sustainable agriculture: A review. Agron. Sustain. Dev. 2014, 34, 1-20. [CrossRef]

51. Duru, M.; Therond, O.; Fares, M. Designing agroecological transitions; A review. Agron. Sustain. Dev. 2015, 35, 1237-1257. [CrossRef]

52. Duru, M.; Therond, O.; Martin, G.; Martin-Clouaire, R.; Magne, M.-A.; Justes, E.; Journet, E.-P.; Aubertot, J.-N.; Savary, S.; Bergez, J.-E.; et al. How to implement biodiversity-based agriculture to enhance ecosystem services: A review. Agron. Sustain. Dev. 2015, 35, 1259-1281. [CrossRef]

53. Ervin, C.A.; Ervin, D.E. Factors affecting the use of soil conservation practices: Hypotheses, evidence, and policy implications. Land Econ. 1982, 58, 277-292. [CrossRef]

54. Willock, J.; Deary, I.J.; McGregor, M.M.; Sutherland, A.; Edwards-Jones, G.; Morgan, O.; Dent, B.; Grieve, R.; Gibson, G.; Austin, E. Farmers' attitudes. Objectives, behaviors, and personality traits: The Edinburgh study of decision making on farms. J. Vocatt. Behav. 1999, 54, 5-36. [CrossRef]

55. Knowler, D.; Bradshaw, B. Farmers' adoption of conservation agriculture: A review and synthesis of recent research. Food Policy. 2007, 32, 25-48. [CrossRef]

56. Caporali, F. Agroecology as a transdisciplinary science for a sustainable agriculture. In Biodiversity, Biofuels, Agroforestry and Conservation Agriculture; Springer: Dordrecht, The Netherlands, 2010; pp. 1-71. [CrossRef]

57. Altieri, M.A.; Nicholls, C.I. Agroecology scaling up for food sovereignty and resiliency. Sustain. Agric. Rev. 2012, 11, 1-29.

58. Hatt, S.; Artru, S.; Brédart, D.; Lassois, L.; Francis, F.; Haubruge, E.; Garré, S.; Stassart, P.M.; Dufrêne, M.; Monty, A.; et al. Towards sustainable food systems: The concept of agroecology and how it questions current research practices. A review. Biotechnol. Agron. Soc. Environ. 2016, 20, 215-224.

59. Mier, M.; Cacho, T.G.; Giraldo, O.F.; Aldasoro, M.; Morales, H.; Ferguson, B.G.; Rosset, P.; Khadse, A.; Campos, C. Bringing agroecology to scale: Key drivers and emblematic cases. Agroecol. Sust. Food. 2018, 42, 637-665.

60. Dabney, S.M.; Delgado, J.A.; Reeves, D.W. Using Winter cover crops to improve soil and water quality. Commun. Soil Sci. Plant Anal. 2001, 32, 1221-1250. [CrossRef]

61. Altieri, M.A. Agroecology, small farms, and food sovereignty. Mon. Rev. 2009, 61, 102-113. [CrossRef]

62. Rusch, A.; Bommarco, R.; Jonsson, M.; Smith, H.G.; Ekbom, B. Flow and stability of natural pest control services depend on complexity and crop rotation at the landscape scale. J. Appl. Ecol. 2013, 50, 345-354. [CrossRef]

63. Kaye, J.P.; Quemada, M. Using cover crops to mitigate and adapt to climate change. A review. Agron. Sustain. Dev. 2017, 37, 4. [CrossRef]

64. Sharma, N.K.; Stingh, R.J.; Mandal, D.; Kumar, A.; Alam, N.M.; Keesstra, S. Increasing farmer's income and reducing soil erosion using intercropping in rainfed maize-wheat rotation of Himalaya, India. Agric. Ecosyst. Environ. 2017, 247, 43-53. [CrossRef]

65. Weißhuhn, P.; Reckling, M.; Stachow, U.; Wiggering, H. Supporting agricultural ecosystem services through the integration of perennial polycultures into crop rotations. Sustainability 2017, 9, 2267. [CrossRef] 
66. Zhou, Y.; Zhu, H.; Yao, Q. Improving soil fertility and soil functioning in cover cropped agroecosystems with symbiotic microbes. In Agro-Environmental Sustainability; Singh, J.S., Seneviratne, G., Eds.; Springer: Berlin, Germany, 2017; pp. 149-171.

67. Navntoft, S.; Wratten, S.D.; Kristensen, K.; Esbjerg, P. Weed seed predation in organic and conventional fields. Biol. Control. 2009, 49, 11-16. [CrossRef]

68. Bonanomi, G.; De Filippis, F.; Cesarano, G.; La Storia, A.; Ercolini, D.; Scala, F. Organic farming induces changes in soil microbiota that affect agroecosystem functions. Soil Biol. Biochem. 2016, 103, 327-336. [CrossRef]

69. Kuemmel, B. Theoretical investigation of the effects of field margin and hedges on crop fields. Agric. Ecosyst. Environ. 2003, 95, 387-392. [CrossRef]

70. Van Vooren, L.; Reubens, B.; Broekx, S.; De Frenne, P.; Nelissen, V.; Pardon, P.; Verheyen, K. Ecosystem service delivery of agri-environment measures: A synthesis for hedgerows and grass strips on arable land. Agric. Ecosyst. Environ. 2017, 244, 32-51.

71. Van Vooren, L.; Reubens, B.; Ampoorter, E.; Broekx, S.; Pardon, P.; Van Waes, C.; Verheyen, K. Monitoring the impact of hedgerows and grass strips on the performance of multiple ecosystem service indicators. Environ. Manag. 2018, 62, 241-259. [CrossRef] [PubMed]

72. Lal, R.; Kimble, J.M. Conservation tillage for carbon sequestration. Nutr. Cycl. Agroecosyst. 1997, 49, $243-253$. [CrossRef]

73. Holland, J.M. The environmental consequences of adopting conservation tillage in Europe: Reviewing the evidence. Agric. Ecosyst. Environ. 2004, 103, 1-25. [CrossRef]

74. Roldán, A.; Salinas-García, J.R.; Alguacil, M.M.; Caravaca, F. Changes in soil enzyme activity, fertility, aggregation and $C$ sequestration mediated by conservation tillage practices and water regime in a maize field. Appl. Soil Ecol. 2005, 30, 11-20. [CrossRef]

75. Soane, B.D.; Ball, B.C.; Arvidsson, J.; Basch, G.; Moreno, F.; Roger-Estrade, J. No-till northern, western and south-western Europe: A review of problems and opportunities for crop production and the environment. Soil Till. Res. 2012, 118, 66-87. [CrossRef]

76. Lairon, D. Nutritional quality and safety of organic food. Agron. Sustain. Dev. 2010, 30, 33-41. [CrossRef]

77. Ahmed, S.; Stepp, J.R. Beyond yields: Climate change effects on specialty crop quality and agroecological management. Elem.-Sci. Anthrop. 2016, 4, 92. [CrossRef]

78. Gomiero, T. Food quality assessment in organic vs. conventional agricultural produce: Findings and issues. Appl. Soil. Ecol. 2017. [CrossRef]

79. Gliessman, S. Transforming food systems to sustainability with agroecology. J. Sustain. Agric. 2011, 35, 823-825. [CrossRef]

80. McKay, B. A Socially Inclusive Pathway to Food Security: The Agroecological Alternative; Bureau for Development Policy, United Nations Development Programme and the Government of Brazil: New York, NY, USA, 2012; Volume 23. Available online: http:/ / hdl.handle.net/1765/50349 (accessed on 19 November 2018).

81. Declaration of the International Forum for Agroecology, Nyéléni, Mali, 27 February 2015. Available online: https:/ /link.springer.com/article/10.1057/s41301-016-0014-4 (accessed on 19 November 2018).

82. Regulation (EU) No 1305/2013 of the European Parliament and of the Council of 17 December 2013 on Support for Rural Development by the European Agricultural Fund for Rural Development (EAFRD) and Repealing Council Regulation (EC) No 1698/2005. OJEU 20.12.2013. Available online: https://eur-lex. europa.eu/LexUriServ/LexUriServ.do?uri=OJ:L:2013:347:0487:0548:en:PDF (accessed on 13 June 2018).

(C) 2018 by the authors. Licensee MDPI, Basel, Switzerland. This article is an open access article distributed under the terms and conditions of the Creative Commons Attribution (CC BY) license (http://creativecommons.org/licenses/by/4.0/). 